\title{
CHEWING LICE (PHTHIRAPTERA: AMBLYCERA, ISCHNOCERA) FROM SOME WILD BIRDS IN THE KIZILIRMAK DELTA (TURKEY)
}

\author{
MUSTAFA AÇICI, COSTICĂ ADAM, ALI TÜMAY GÜRLER, \\ KİRAZ ERCIYAS, CENK SONER BÖLÜKBAŞ, ŞİNASİ UMUR
}

\begin{abstract}
We present the results of the studies on the chewing lice collected during the period 2009-2010 from 32 wild birds belonging to 11 species, in the Kiz1lırmak Delta of Turkey. From the 13 chewing louse species identified in the studied material, six of them are new records for the parasitological fauna of Turkey, namely: Ricinus fringillae De Geer, 1778 ex Fringilla coelebs; Cuculicola latirostris (Burmeister, 1838) ex Cuculus canorus; Brueelia domestica (Kellogg \& Chapman, 1899) ex Hirundo rustica; Brueelia merulensis (Denny, 1842) ex Turdus merula; Brueelia turdinulae Ansari, 1956 ex Turdus philomelos; and Penenirmus affectator (Złotorzycka, 1976) ex Sylvia borin. Also, the following two new chewing louse - bird species associations are reported for the first time all over the world: Quadraceps anagrapsus (Nitzsch [in Giebel], 1866) ex Sterna albifrons; and Penenirmus sp. ex Sylvia melanocephala. The presence of a chewing louse species is reported on $S$. melanocephala for the first time in the world. And not the least, it is reported, for the first time, the presence of three chewing louse species - bird species associations in the Turkish parasitological fauna: Menacanthus curuccae (Schrank, 1776) ex Acrocephalus scirpaceus and Sylvia borin; and Menacanthus eurysternus (Burmeister, 1838) ex Turdus merula.
\end{abstract}

Résumé. On présente les résultats de l'étudie contre les mallophages collectées au cours de la période 2009-2010 sur 32 oiseaux sauvages appartenir à 11 espèces, dans le delta K1zılırmak de la Turquie. Entre les 13 espèces de mallophages identifies dans le matériel analysé, six sont des nouveaux, signalés pour la faune parasitologique de la Turquie, à savoir: Ricinus fringillae De Geer, 1778 sur Fringilla coelebs; Cuculicola latirostris (Burmeister, 1838) sur Cuculus canorus; Brueelia domestica (Kellogg \& Chapman, 1899) sur Hirundo rustica; Brueelia merulensis (Denny, 1842) sur Turdus merula; Brueelia turdinulae Ansari, 1956 sur Turdus philomelos; et Penenirmus affectator (Złotorzycka, 1976) sur Sylvia borin. Aussi sont signalées pour la première fois dans le monde les suivants deux nouvelles associations espèces mallophage - espèces oiseaux: Quadraceps anagrapsus (Nitzsch [in Giebel], 1866) sur Sterna albifrons; et Penenirmus sp. sur Sylvia melanocephala. On a signalée pour la première fois dans le monde la présence d'une espèce de mallophage sur $S$. melanocephala. Et non des moindres, on a signalée pour la première fois dans la faune parasitologique de la Turquie, l'existence de trois associations espèces mallophages - espèces oiseaux: Menacanthus curuccae (Schrank, 1776) sur Acrocephalus scirpaceus et Sylvia borin; et Menacanthus eurysternus (Burmeister, 1838) sur Turdus merula.

Key words: Phthiraptera, chewing lice, wild birds, the Kiz1lırmak Delta, the Black Sea, Turkey. 


\section{INTRODUCTION}

Chewing lice are relatively benign parasites. When present in large numbers, they can cause severe irritation and reduced host survival and reproductive success (Clayton et al., 2008). Therefore, the knowledge of this group of ectoparasites has also an important practical applicative importance besides the theoretical one. In spite of this, up to now, the chewing lice were relatively less studied in Turkey. An analyse of the knowledge of the chewing louse fauna on the birds of Turkey was recently published by İnci et al. (2010). Taking into account the data given by this paper of synthesis (İnci et al., op. cit.), and also by the subsequent ones (Dik et al., 2011; Dik, Şekercioğlu \& Kirpik, 2011; Dik, Yamaç \& Uslu, 2011), we can assert that, for the time being, in Turkey only 95 chewing louse species belonging to 44 genera (46 species belonging to 17 amblyceran genera, and the other 49 species belonging to 27 ischnoceran genera) were reported from birds. In this estimation, we haven't included those reports based on an identification till the genus level.

Taking into consideration that the Turkish avifauna is estimated at 491 birds species at present, according to the data given by Lepage (2011) (including the wild species occurred accidentally, from wildlife), as well as the parasite chewing louse species from them, then the parasite chewing louse fauna from birds of Turkey could be estimated to over 900 species. Analysing these data, it can be established that, at present, in the Turkish territory, less than $10 \%$ of the total number of chewing louse species possibly present in the fauna of this country were reported, thus the necessity of continuing and deepening the studies in this direction distinguishing. Starting from this necessity, we proposed to study the chewing louse fauna from the occurred birds in one of the most important areas from the avifaunal point of view of Turkey that is the delta of the Kiz1lirmak River. Within this area, such kind of studies was not made till now.

The Kizilırmak Delta is one of the largest deltas on the Turkish territory, formed at the mouth of the Kizılirmak River (the longest river of Turkey) at the Black Sea, in the central-northern part (coordinates of the river mouth: $41^{\circ} 44^{\prime} \mathrm{N}$, $35^{\circ} 57^{\prime}$ E) (Fig. 1). This delta lays to the north of Bafra locality (Fig. 2), by both sides of the river, on a surface of over 56000 ha, including a very large range of habitat types (lakes; reed areas; freshwater marshes and swamps; watery meadows; pastures; forests; dunes; coastal lakes; lagoons; and agricultural areas). At present, in this area, the presence of 331 bird species was reported, out of which 124 are passerine species (Bariş et al., 2010).

By the results of our studies, included in this paper, which are, as a matter of fact, preliminary, and by their reporting to those already published in the specialized literature, we succeeded in completing both the world list of the bird species-chewing louse species associations (host-parasite) and the faunal list of the parasite chewing lice from the wild birds of Turkey. 


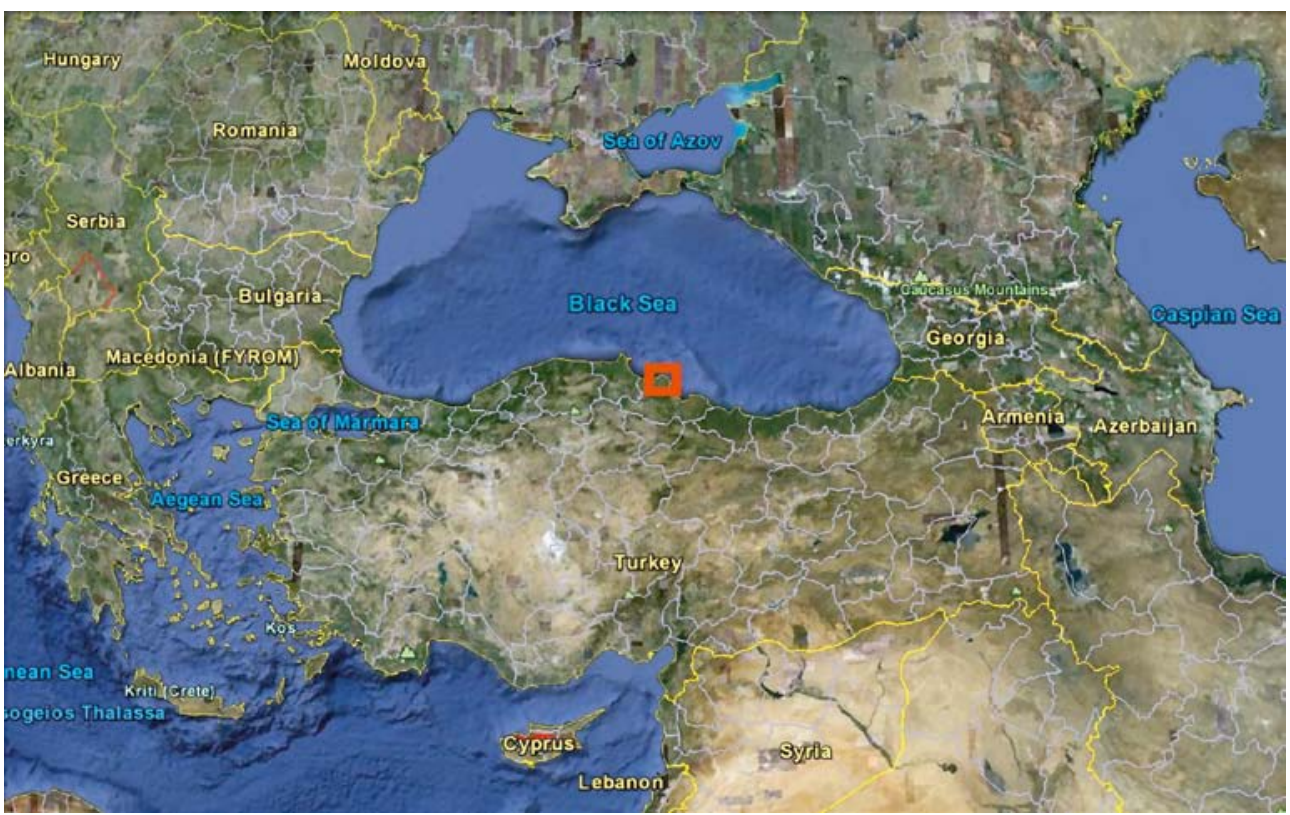

Fig. 1 - Geographical position of the Kizılırmak Delta (adapted from Google Earth).

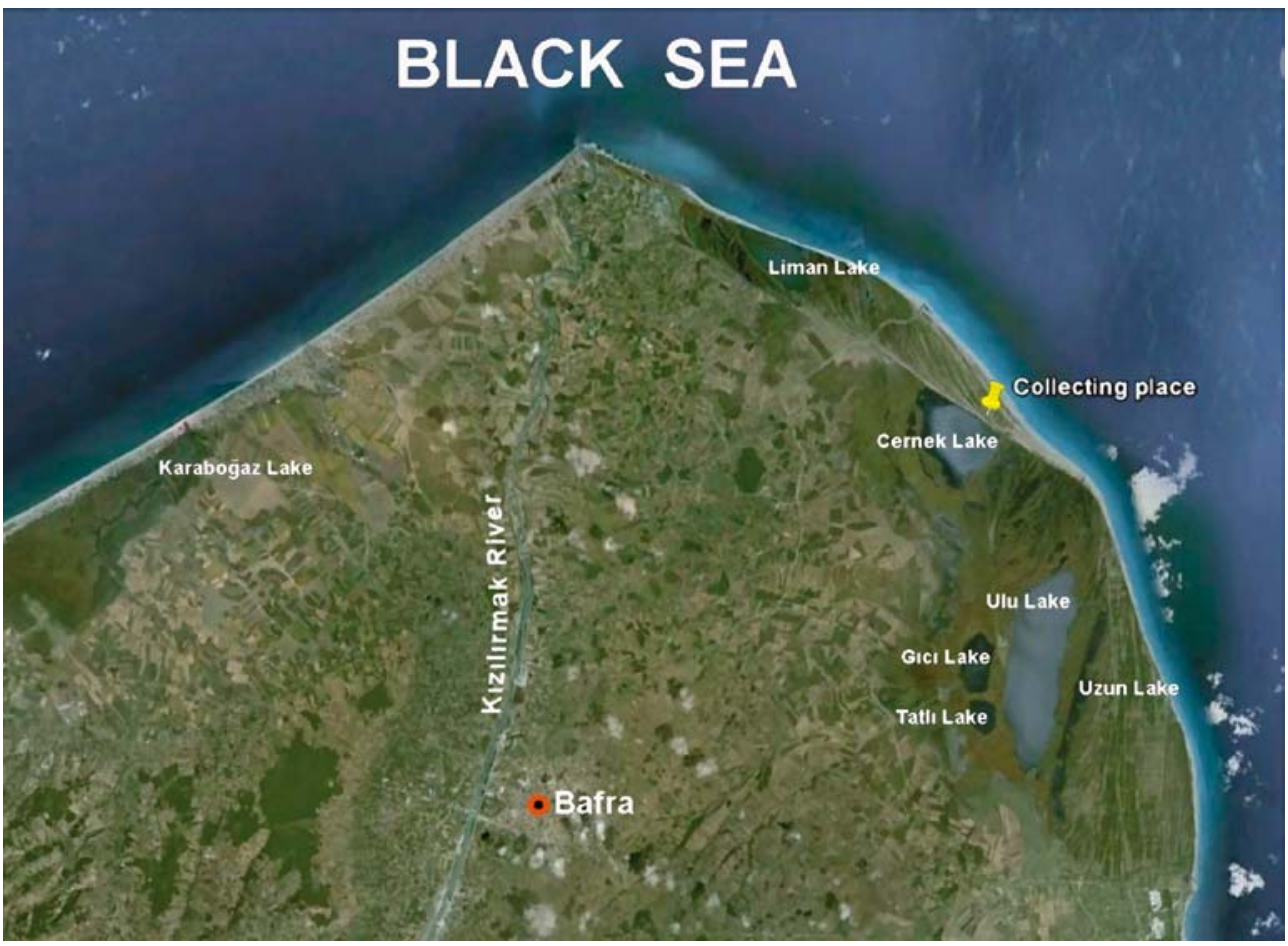

Fig. 2 - Geographical position of collecting place in the Kizılırmak Delta (adapted from Google Earth). 


\section{MATERIAL AND METHOD}

Studied material was collected within the period 2009-2010. Studied birds were captured in an area between Cernek Lake and the Black Sea coast, close to Cernek Birdring \& Birdwatch Station, GPS coordinates of the collecting place being $41^{\circ} 38.843$ ' N, $36^{\circ} 04.841^{\prime}$ E (Fig. 2). Birds were captured with mist nets, and the ectoparasitological material collected from them was labelled and preserved in $70 \%$ alcohol.

Totally, a number of 189 birds, which belong to 37 species of 18 families and 6 orders, were examined. From all these examined birds, we found chewing lice only on 32 individuals (belonging to 11 species of 8 families and 3 orders). On the other 157 birds (belonging to 34 species of 16 families and 5 orders) (Tab. 1) we did not find chewing lice. Total prevalence of the chewing louse infestation in the studied birds was of $16.9(\mathrm{n}=189)$. In the case of Podicipediformes, Strigiformes and Coraciiformes orders, the prevalence of the chewing louse infestation was zero. From the other bird orders, the lowest value of the prevalence $(\mathrm{P})$ occurred in Passeriformes $(\mathrm{P}=16.1 ; \mathrm{n}=180)$, and the highest value, in Cuculiformes $(\mathrm{P}=100 ; \mathrm{n}=1)$ and Charadriiformes $(\mathrm{P}=66.6 ; \mathrm{n}=3)$ (Tab. 1). From passeriforms, the most numerous not infested birds were those of the family Sylviidae, and the most numerous infested birds belonged to family Laniidae.

The captured birds were identified using the field guides by Porter et al. (1996) and Porter \& Aspinal (2010), and the taxonomy of the birds followed Clements (2007).

For the chewing lice identification, a part of the collected material was mounted in Canada balsam, following the technique of Palma (1978). The rest of the material is preserved in $70 \%$ alcohol.

Identifications of the chewing lice based on Marshall (2002), Nelson (1972), Palma et al.(1998), Price (1977), Rheinwald (1968; 2007) and Złotorzycka (1976). The scientific names of the chewing lice used in this paper are according to the chewing louse list published by Price et al. (2003).

\section{RESULTS}

From all collected material, 88 chewing louse specimens were identified. Later, these chewing louse specimens were identified as belonging to eight genera and 13 species (Tab. 1). From the 88 collected specimens, 54 are females $(61.36 \%)$, 17 males (19.32\%) and 17 nymphs (19.32\%).

From the chewing lice collected by us, 51 specimens ( 32 females, 10 males and 9 nymphs) (57.95\%) belong to the suborder Amblycera, the best represented being genus Menacanthus ( 38 specimens: 21 females, 8 males and 9 nymphs), and the rest of 37 specimens (22 females, 7 males and 8 nymphs) (42.05\%) belong to the suborder Ischnocera, within it the best represented being genus Brueelia (23 specimens: 12 females, 5 males and 6 nymphs). 


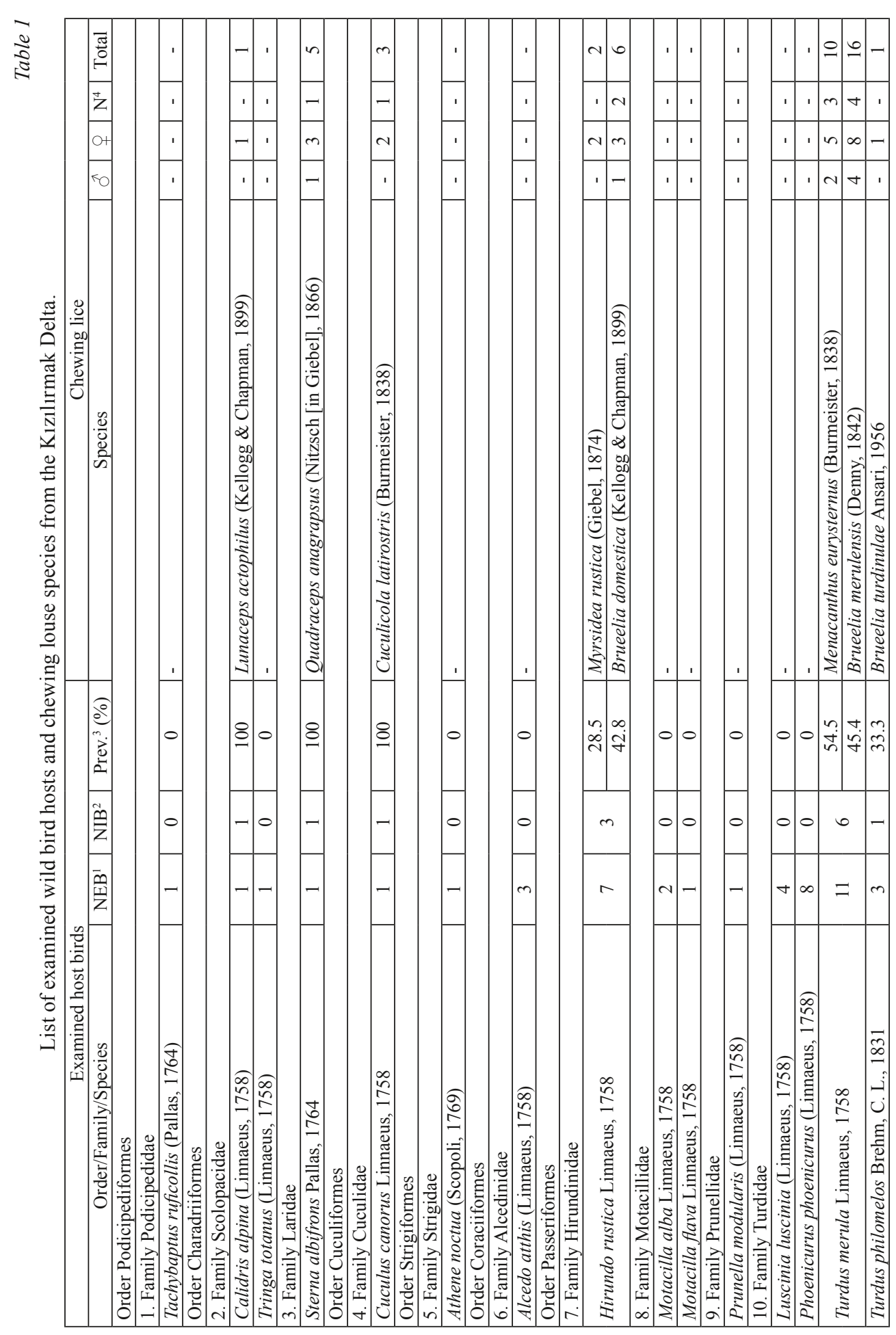




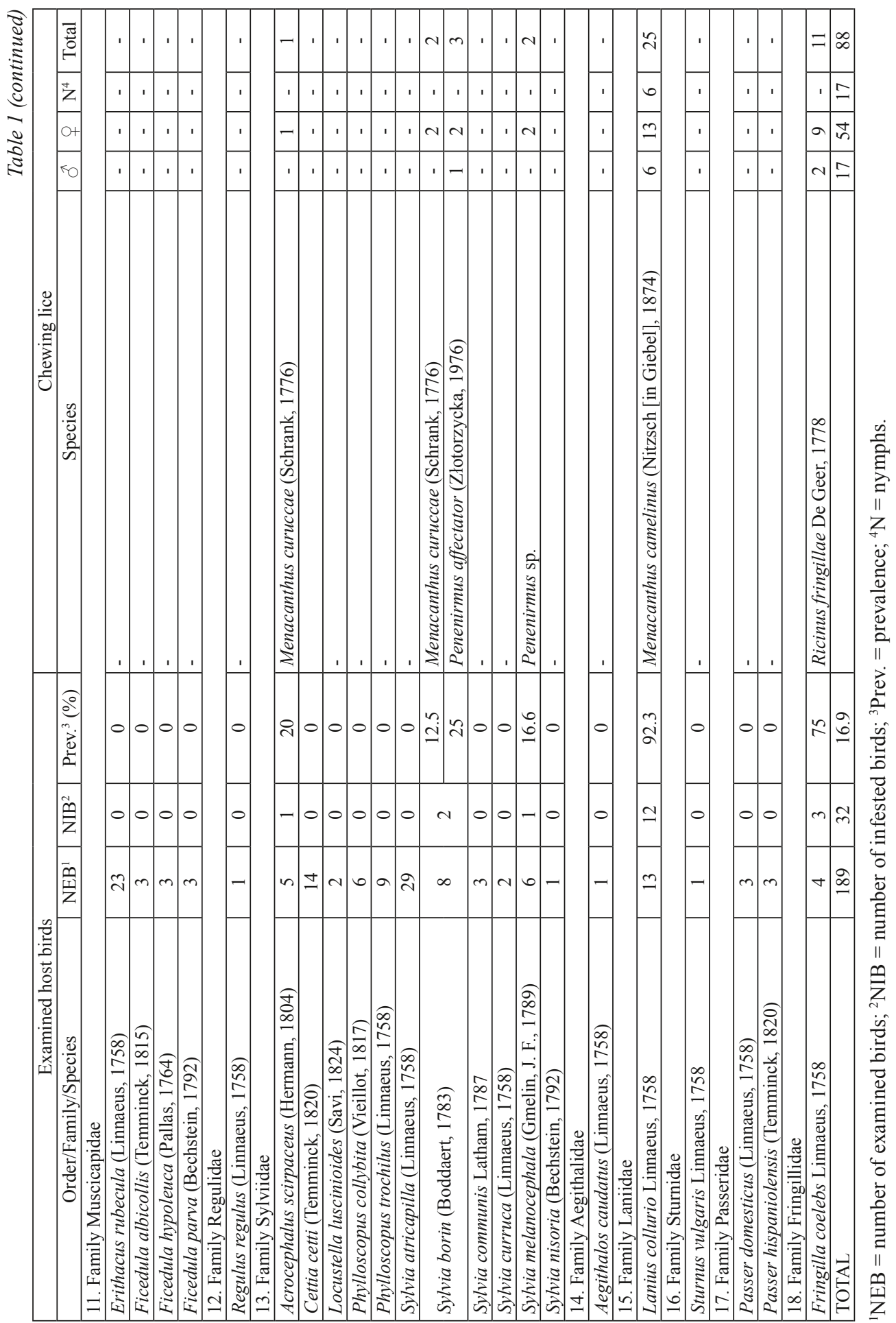


Taking into account the number of species, from the 13 chewing louse species identified by us, 5 (of the three genera and two families) belong to the suborder Amblycera, and 8 (of five genera and a family) belong to the suborder Ischnocera. Also, from the number of species point of view, Menacanthus was the best represented genus of the suborder Amblycera, in our material, with three species, and from the suborder Ischnocera, Brueelia was the best represented genus, also with three species. Therefore, it can be observed that, in our material, amblycerans are prevalent in the specimen number, and ischnocerans, in the species one.

Table 1 includes the systematic list of the host species and chewing louse species, collected and identified. Also in this table, the total number of controlled individuals are mentioned for each bird species, the number of individuals infested with chewing lice and their prevalence, and for the species of collected chewing lice, the number of collected specimens are mentioned (males, females and nymphs).

\section{DISCUSSIONS}

Analysing the data from the specialized literature regarding the chewing louse fauna of Turkey (İnci et al., 2010; Dik et al., 2011; Dik, Șekercioğlu \& Kirpik, 2011; Dik, Yamaç \& Uslu, 2011), published up to now and we were aware, we can assert that from all studied species the next six species, collected from the wild birds, are reported for the first time in the ectoparasitological fauna of this country: Ricinus fringillae De Geer, 1778 ex Fringilla coelebs (Fig. 3 B, C); Cuculicola latirostris (Burmeister, 1838) ex Cuculus canorus (Fig. 3 D); Brueelia domestica (Kellogg \& Chapman, 1899) ex Hirundo rustica (Figs 4 D; 5 A); Brueelia merulensis (Denny, 1842) ex Turdus merula (Fig. 5 B, C); Brueelia turdinulae Ansari, 1956 ex Turdus philomelos (Fig. 5 D); and Penenirmus affectator (Złotorzycka, 1976) ex Sylvia borin (Fig. 6 A).

For the first time throughout the world, we report two new parasite specieshost species associations (unmentioned in the world catalogue published by Price et al. in 2003), which can be considered normal, because it is not about deserting cases, considering that the new hosts which we found are closely related to the hosts they were reported before. It is about the following chewing louse species - bird species associations, namely: Quadraceps anagrapsus (Nitzsch [in Giebel], 1866) ex Sterna albifrons (Fig. 4 A, B, C); and Penenirmus sp. ex Sylvia melanocephala (Fig. 6 B).

We report, for the first time in the world, the presence of the chewing louse genus Penenirmus on the bird species Sylvia melanocephala, this chewing louse genus being reported on other species of Sylvia up to now. As a matter of fact, we report for the first time in the world the presence of a chewing louse species on the bird species S. melanocephala. Penenirmus sp. distinguishes from the other species of Penenirmus from the birds of the genus Sylvia especially by some features as: chaetotaxy and morphology of the preantennal part of the head; abdominal tergal, sternal and pleural chaetotaxy; thoracic sternal chaetotaxy; number of the vulval posterior marginal setae. 

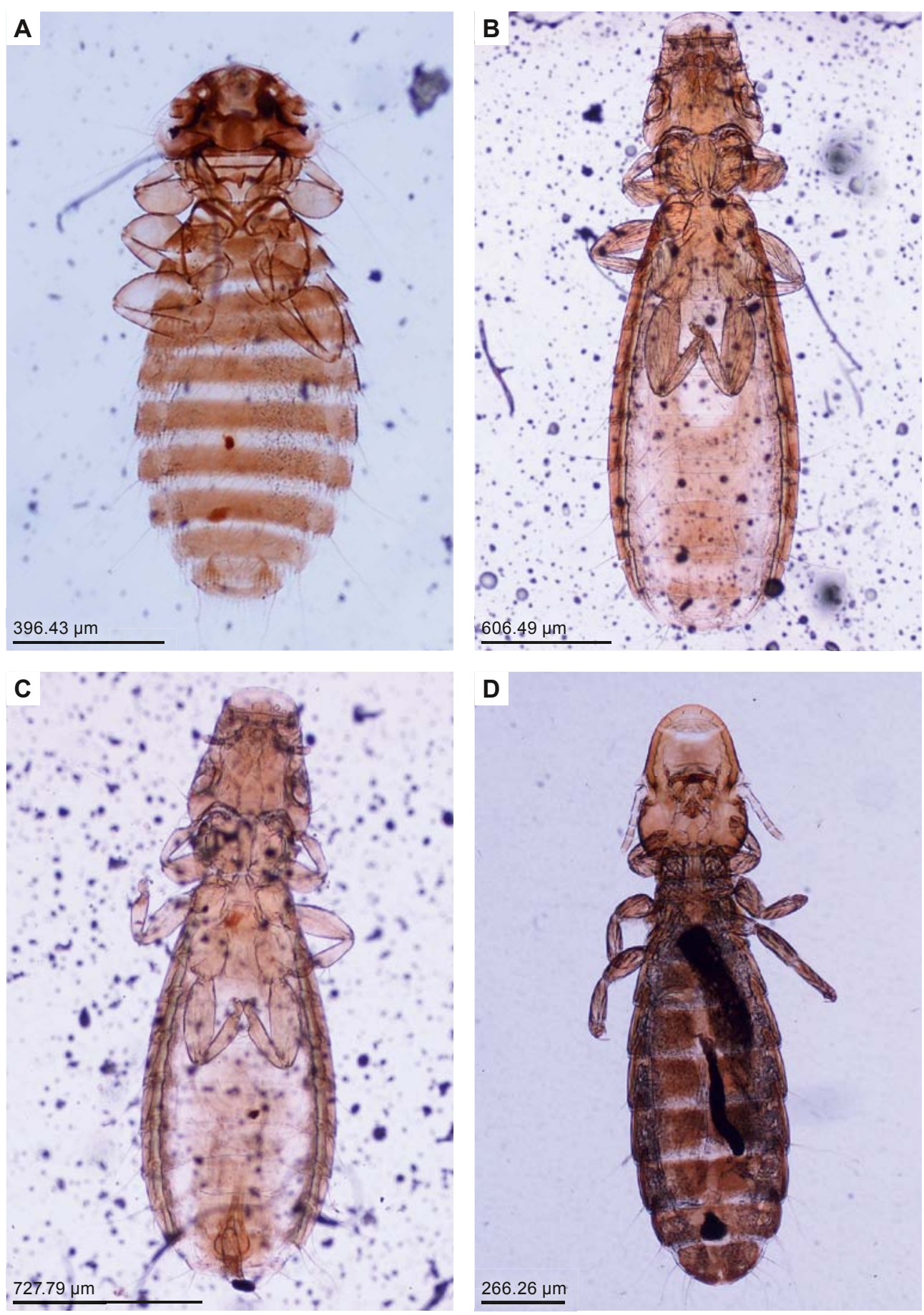

Fig. 3 - Menacanthus curuccae (from Sylvia borin): A, female; Ricinus fringillae (from Fringilla coelebs): B, female; C, male; Cuculicola latirostris (from Cuculus canorus): D, female. 

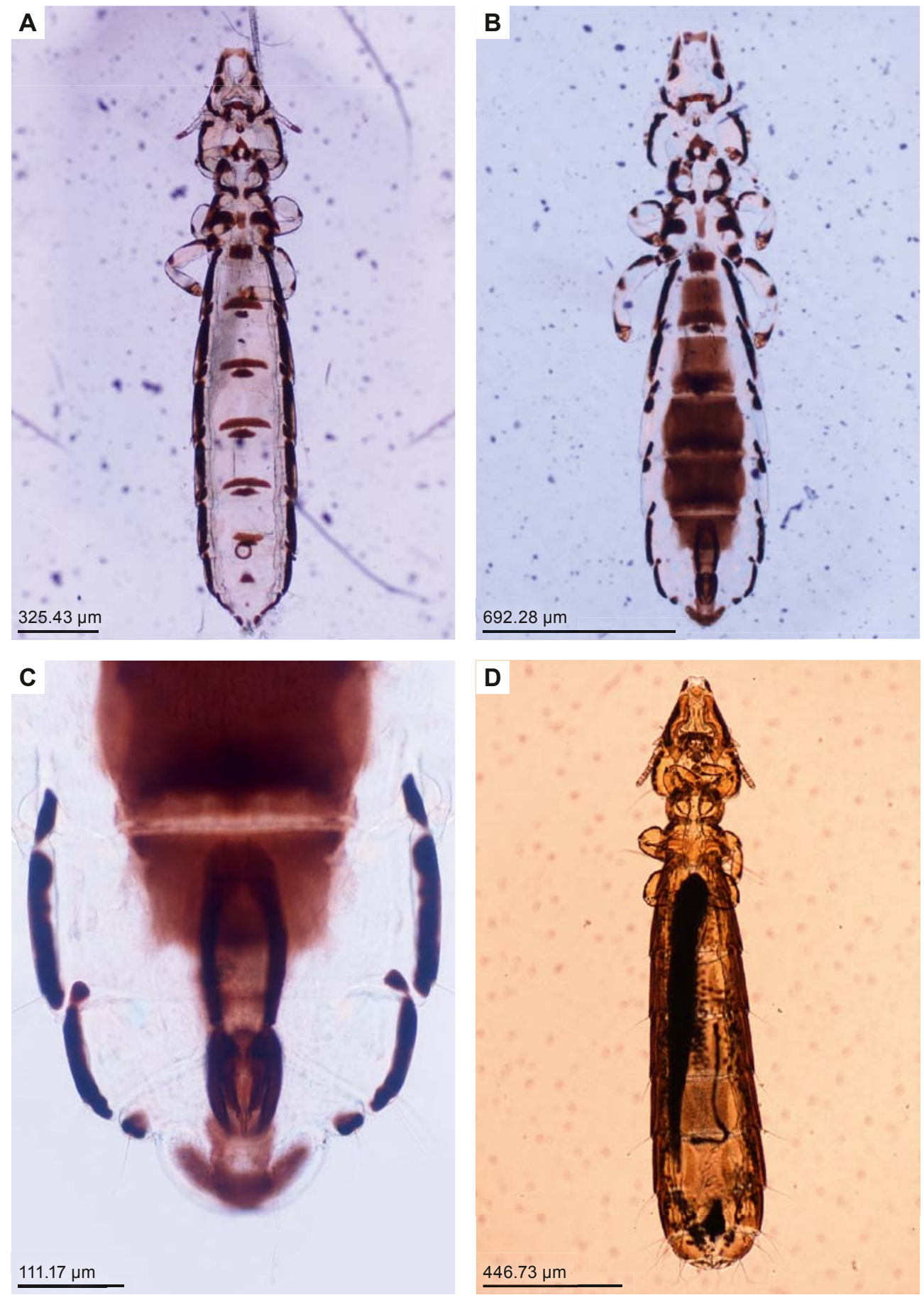

Fig. 4 - Quadraceps anagrapsus (from Sterna albifrons): A, female; B, male; C, male genitalia; Brueelia domestica (from Hirundo rustica): D, female. 

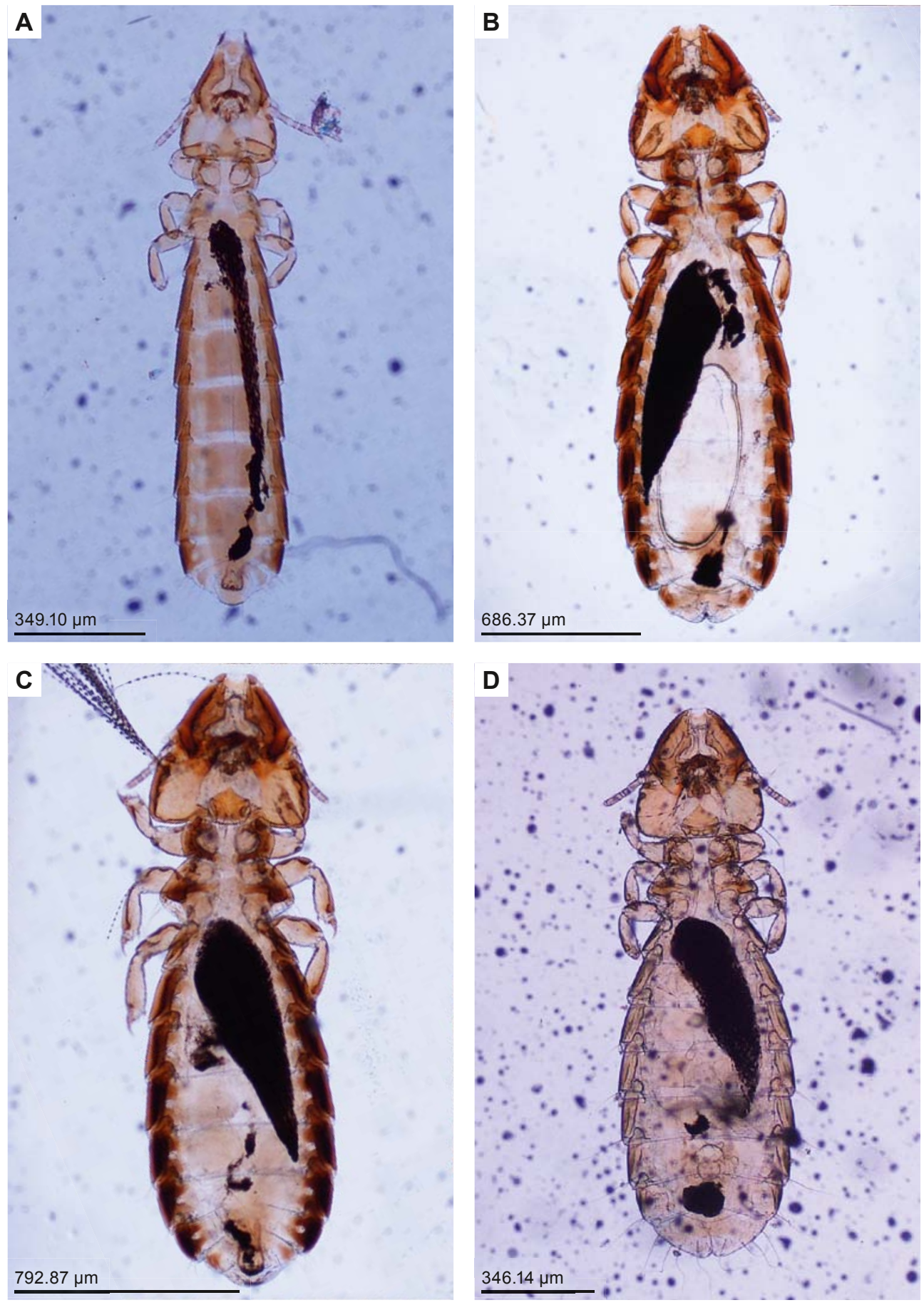

Fig. 5 - Brueelia domestica (from Hirundo rustica): A, male; Brueelia merulensis (from Turdus merula): B, female; C, male; Brueelia turdinulae (from Turdus philomelos): D, female. 

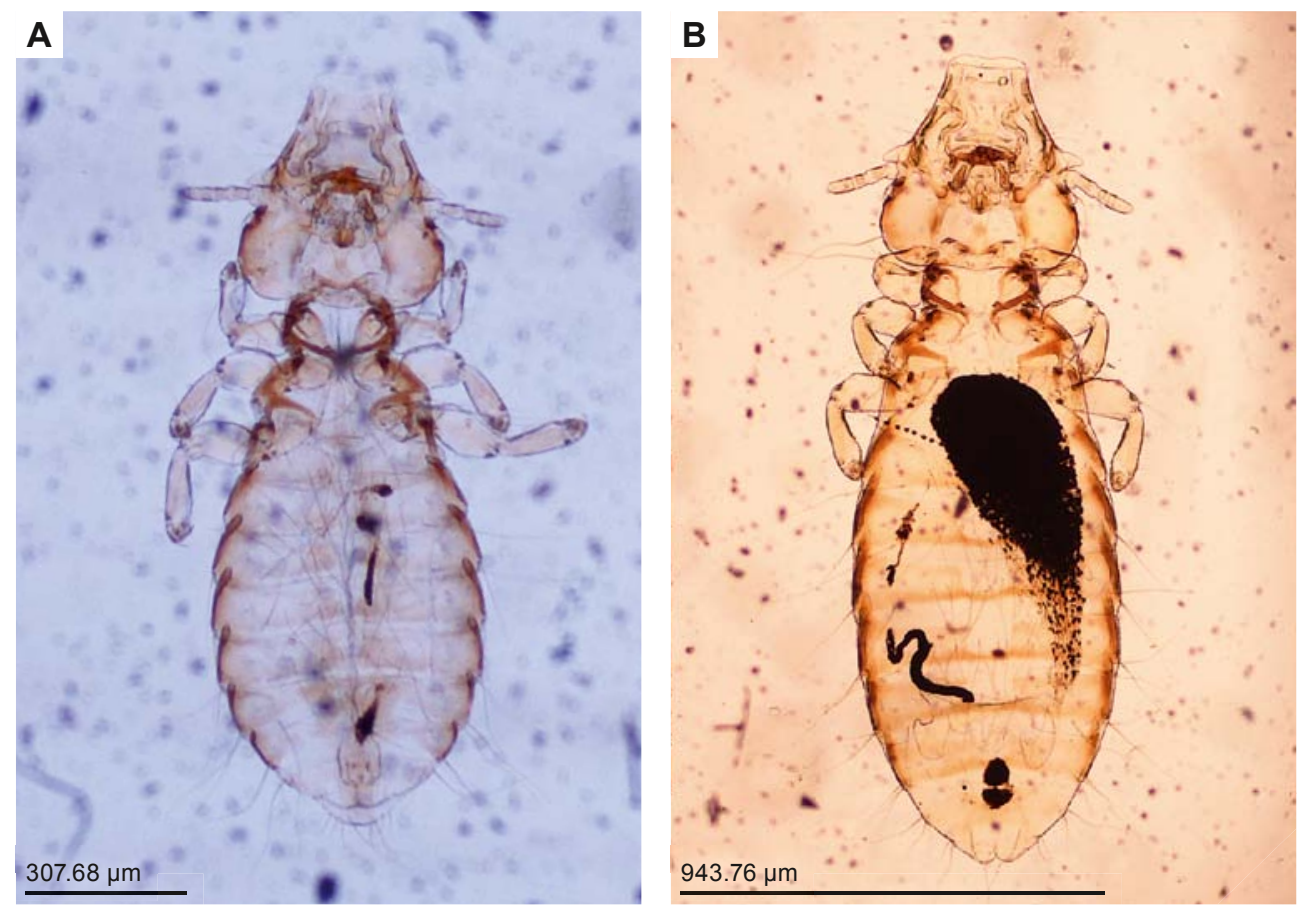

Fig. 6 - Penenirmus affectator (from Sylvia borin): A, male; Penenirmus sp. (from Sylvia melanocephala): $\mathrm{B}$, female.

Q. anagrapsus was reported only on Chlidonias hybridus and Ch. leucopterus (Price et al., 2003) till now, species of the same family with Sterna albifrons, on which we report it now. Normally, S. albifrons is parasited by the species Quadraceps nycthemerus (Burmeister, 1838). The two species differs one another by the following features: body length (longer in $Q$. anagrapsus than in $Q$. nycthemerus); form of the abdominal tergal and sternal plates of the females (Fig. $4 \mathrm{~A}$ ); form of the abdominal pleural plates V and VI in males (in Q. anagrapsus only the anterior part is chitinized, so distinguishing from the rest of the abdominal pleural plates) (Fig. 4 B); and by the conformation of male genitalia (Fig. 4 C).

And not the least, we report for the first time in the parasitological fauna of Turkey, the presence of the following three host-parasite associations: Menacanthus curuccae (Schrank, 1776) ex Acrocephalus scirpaceus and Sylvia borin (Fig. 3 A); and Menacanthus eurysternus (Burmeister, 1838) ex Turdus merula.

The results of the present survey add data to the limited epidemiological information regarding chewing louse faunal composition in wild birds from the Black Sea region of Turkey. 


\section{ACKNOWLEDGEMENTS}

We thank to the anonymous scientific referees for their useful advice for drawing up this paper. Costică Adam was supported by UEFISCDI (The Executive Agency for Higher Education, Research, Development and Innovation Funding, Romania), project PNCDI II - RU - PD-284/2010.

Parts of the article were submitted in the Fourth International Conference on Phthiraptera (June 13-18, 2010) Urgup, Cappadocia, Turkey and XVII ${ }^{\text {th }}$ National Parasitology Congress and Caucasian and Middle East Symposium on Parasitic Diseases (September 4-10, 2011), Kars, Turkey, as poster presentations.

\section{MALOFAGE (PHTHIRAPTERA: AMBLYCERA, ISCHNOCERA) DE PE UNELE PĂSĂRI SĂLBATICE DIN DELTA KIZILIRMAK (TURCIA)}

\section{REZUMAT}

Sunt prezentate rezultatele cercetării asupra malofagelor colectate în perioada 2009-2010 de pe 32 de păsări aparţinând la 11 specii, în Delta Kızılırmak din Turcia. Dintre cele 13 specii de malofage identificate în materialul cercetat, șase reprezintă semnalări noi pentru fauna parazitologică a Turciei, şi anume: Ricinus fringillae De Geer, 1778 de pe Fringilla coelebs; Cuculicola latirostris (Burmeister, 1838) de pe Cuculus canorus; Brueelia domestica (Kellogg \& Chapman, 1899) de pe Hirundo rustica; Brueelia merulensis (Denny, 1842) de pe Turdus merula; Brueelia turdinulae Ansari, 1956 de pe Turdus philomelos; și Penenirmus affectator (Złotorzycka, 1976) de pe Sylvia borin. De asemenea, sunt semnalate pentru prima dată în lume următoarele două asocieri noi specie malofag - specie pasăre: Quadraceps anagrapsus (Nitzsch [in Giebel], 1866) de pe Sterna albifrons; și Penenirmus sp. de pe Sylvia melanocephala. Pe S. melanocephala se semnalează pentru prima dată în lume prezenţa unei specii de malofag. Şi nu în ultimul rând, este semnalată pentru prima dată existenţa în fauna parazitologică a Turciei a trei asocieri specie malofag - specie pasăre: Menacanthus curuccae (Schrank, 1776) de pe Acrocephalus scirpaceus și Sylvia borin; și Menacanthus eurysternus (Burmeister, 1838) de pe Turdus merula.

\section{LITERATURE CITED}

BARIŞ, Y. S., Ö. SAĞLAM, K. ERCIYAS, N. YAVUZ, A. C. ÖZSEMIR, 2010 - An Important Natural Heritage: the Kızılırmak Delta - Birds. Doğa ve Yaban Hayatı Koruma Derneği, Samsun, Turkey. 169 pp.

CLAYTON, D. H., R. J. ADAMS, S. E. BUSH, 2008 - Phthiraptera, the Chewing lice. Pp. 515-526. In: C. T. Atkinson, N. J. Thomas, D. B. Hunter (eds), Parasitic Diseases of Wild Birds, WileyBlackwell, Ames, Iowa, USA. 595 pp.

CLEMENTS, J. F., 2007 - The Clements Checklist of Birds of the World, $6^{\text {th }}$ edition. Cornell University Press. 855 pp.

DIK, B., C. H. ŞEKERCIOĞLU, M. A. KIRPIK, 2011 - Chewing lice (Phthiraptera) species found on birds along the Aras River, Iğdır, Eastern Turkey. Kafkas Universitesi Veteriner Fakultesi Dergisi, 17 (4): 567-573.

DIK, B., E. E. YAMAÇ, U. USLU, 2011 - Chewing lice (Phthiraptera) found on wild birds in Turkey. Kafkas Universitesi Veteriner Fakültesi Dergisi, 17 (5): 787-794.

DIK, B., M. A. KIRPIK, C. ŞEKERCIOĞLU, Y. ȘAȘMAZ, 2011 - Chewing lice (Phthiraptera) found on songbirds (Passeriformes) in Turkey. Türkiye Parazitoloji Dergisi, 35: 34-39.

İNCİ, A., A. YILDIRIM, B. DIK, O. DÜZLÜ, 2010 - Current knowledge of Turkey's louse fauna. Türkiye Parazitoloji Dergisi, 34: 212-220.

LEPAGE, D., 2011 - Checklist of the birds of Turkey. Avibase, the world bird database. Retrieved from http://avibase.bsceoc.org/checklist.jsp?lang=EN\&region=tr\&list=clements on 23/12/2011.

MARSHALL, I. K., 2002 - Congruence and Cospeciation: Morphological and Molecular Phylogenetics of the Amblycera (Phthiraptera). Unpublished PhD thesis, University of Glasgow. $253 \mathrm{pp}$. 
NELSON, B. C., 1972 - A revision of the New World species of Ricinus (Mallophaga) occuring on Passeriformes (Aves). University of California Publications in Entomology, 68: 1-175.

PALMA, R. L., 1978 - Slide mounting of lice: a description of the Canada balsam technique. New Zealand Entomologist, 6 (4): 432-436.

PALMA, R. L., R. D. PRICE, R. A. HELLENTHAL, 1998 - New synonymies and host records for lice of the genus Menacanthus (Phthiraptera: Menoponidae) from the Passeriformes (Aves). Journal of the Royal Society of New Zealand, 28 (2): 309-320.

PORTER, R., S. ASPINALL, 2010 - Birds of the Middle East (Second Edition). Published by Christopher Helm, London. 384 pp.

PORTER, R. F., S. CHRISTENSEN, P. SCHIERMACKER-HANSEN, 1996 - Field Guide to the Birds of the Middle East. T. \& A. D. Poyser, London. 480 pp.

PRICE, R. D., 1977 - The Menacanthus (Mallophaga: Menoponidae) of the Passeriformes (Aves). Journal of Medical Entomology, 14: 207-220.

PRICE, R. D., R. A. HELLENTHAL, R. L. PALMA, 2003 - World checklist of chewing lice with host associations and keys to families and genera. Pp. 1-448. In: R. D. Price, R. A. Hellenthal, R. L. Palma, K. P. Johnson, D. H. Clayton, The Chewing Lice: World Checklist and Biological Overview, Illinois Natural History Survey Special Publication 24. x 501 pp.

RHEINWALD, G., 1968 - Die Mallophagengattung Ricinus De Geer, 1778. Revision der ausseramerikanischen Arten. Mitteilungen aus dem Hamburgischen Zoologischen Museum und Institut, 65: 181-326.

RHEINWALD, G., 2007 - The Position of Trochiliphagus Carriker within the Ricinidae (Insecta: Phthiraptera). Bonner Zoologische Beitrage, 55 (1): 37-46.

ZŁOTORZYCKA, J., 1976 - Europaische Arten der Mallophagen-Gattung Pleurinirmus. Angewandte Parasitologie, 17: 208-214.

*** Google Earth - earth.google.com/

Received: October 17, 2011

Accepted: December 26, 2011
Mustafa Açici, Ali Tümay Gürler, Cenk Soner Bölükbaş, Şinasi Umur Department of Parasitology, Faculty of Veterinary Medicine, Ondokuz Mayıs University 55137 Atakum-Samsun, Turkey

Costică Adam (corresponding author)

"Grigore Antipa" National Museum of

Natural History,

Şos. Kiseleff no. 1, 011341 Bucharest 1, Romania

e-mail: cadam@antipa.ro

Kiraz Erciyas

Ornithology Research Center,

Ondokuz Mayıs University

55137 Atakum-Samsun, Turkey 